[ANmals N. Y. ACAd. SCI., XI, No. 10, pp. 193 to 217, July 29, 1898.]

\title{
DESCRIPTION OF SOME MARINE NEMERTEANS OF PUGET SOUND AND ALASKA.
}

\author{
B. B. Grifrin.
}

(Read Murch 24, IBs.)

Bradney Beverley Griffin died of pneumonia on March 26th-less than a fortnight after the present paper was read before the Academy. The editor of the Avsuls has now sent me the proof for revision and has arranged that a brief notice of his life and work should be inserted as its preface.

Mr. Griffin came rightfully by his deep interest in science, for his forefathers on both sides had been prominent in the learned professions, that of medicine especially. His father, Dr. Bradney Griffin, although dying young, was a well-known practitioner in New York. Mr. Grifin's mother is of the Hollister family: his patemal grandmother was a du Barrière, one of whom together with other nobles emigrated to this country during the French Revolution.

Mr. Griffin received his first degree in 1894, gradiating with highest honors, at the College of the City of New York. He there evinced a remarkable bent for zoology. Continuing his studies in the graduate Department of Columbia University he would have taken the Degree of Doctor of Philosophy at the present Commencement. He had held the position of University Fellow in Zoology and had taken part for two years in the summer expeditions to the northwest coast. 
His published writings appear, with one exception, in the Transactions of the Academy. Their results are of permanent value and have already received marked attention both in this country and abroad. His mind was mature and none of us knew before his death that he was but twenty-six. His work showed to all, as memorial notices in foreign journals testify, that he was an investigator of rare promise; but those who knew him well can alone understand how much he would have contributed to zoological knowledge had his life been spared. I have never known a more perfect example of sacrificing devotion to a life's work. 'He gave his best energy-more than his health could spare-to zoölogy for zoölogy's sake. Personally, he was retiring, asked for nothing and cared for nothing in the way of naterial advancement. His industry was incessant, and was rarely directed in vain; he was conscientious even to the least of things; he made it clear to us that his ideals were the highest and that he did as he believed.

Columita Untversity, July 12,1898 :

Bashford Dean.

Published Writings iy Mr. Griffin.

' 96. The History of the Achromatic Structures in the maturation and fertilization of Thalassema. Trans. N. Y. Acad. Sci., Vol. XV, pp. 163-176, pls. IX-XI.

' 97 (I) A brief account of the work of collecting in Puget Sound and on the Pacific coast. (With others.) Ibid., Vol. XVI, pp. 33-43, pl. I.

(2) Notes on the distribution and habits of some Puget Sound nvertebrates. (With N. R. Harrington.) Ibid., pp. 1 52-165.

(3) Adaptation of the shell of Placuanomia to that of Saxilomus, with remarks on shell adaptation in general. Ibid., pp. $7-99$.

' 98 (I) Description of some marine Nemerteans of Puget iound and Alaska. '(The present paper.)

(2) The Maturation and Fertilization of Thalassema. A hesis for the degree of Doctor of Philosophy. Jourual of Morhology. (Shortly to appear.) 


\section{INTRODUCTION.}

The forms here described were collected by the writer while a member of the Columbia University expeditions of 1896 and 1897 to Puget Sound and Alaska. During the first of the summers spent on the Pacific coast about 10-15 different forms were collected, all from the region about Port Townsend, Washington. The work of the second summer added about 15 Alaskan forms to the collection, besides three additional species from Puget Sound.

Upon the return the writer lost by shipwreck not only the Alaskan material, but all the previously prepared sections and much valuable literature, together with manuscripts including notes upon the color, form, habits and habitats of the living animals. The consequent necessity of replacing the literature and resectioning the entire set of forms has, as may be readily understood, greatly delayed the publication of the specific descriptiöns.

The collections were made with the view of accumulating material for a monograph of the Nemerteans of the Pacific coast of the United States, and it is hoped that the present brief notice will be followed by a more extensive work with colored plates. The special interest attaching to certain of the forms (e.g., Carinoma), as well as the general importance of the formal peculiarities of heretofore unexplored regions, will, it is hoped, prove a sufficient excuse for the publication of the present paper.

The species here described do not represent the entire number collected, since, in addition to those lost by shipwreck, scveral have been omitted in which the material was either too poorly preserved or too scanty for adequate determination.

As regards terminology, Montgomery's term ('96) mesenchyme will be used to designate that tissue formerly known as "parenchyme," "body-parenchyme" and "gelatinous tissue." The four vascular trunks of the mesonemerteans will be distinguished as dorso-lateral and ventro-lateral vessels (= respectively "Rhynchocölomseitengefâsse" and "Seitengefasse " of Bürger, "supra-proboscidian-sheath-vessels" and "blood vessel" of Oudemans). 
The writer wishes to express his grateful acknowledgements to Professor H. P. Johnson, of the University of California, for his very kind assistance in obtaining southern specimens of Emplecton:ma viride Stimpson. He also feels indebted to Mr. Mutty, of Port Townsend, for his permission to use one of his' buildings as a laboratory, and to Mr. Shaffer for his kind loan of collecting appliances.

\section{HISTORICAL.}

During the years $1857-58$ there appeared in the Procedings of the Philadelphia Academy a series of preliminary papers by Dr. William Stimpson, in which he briefly described the invertebrates collected upon the North Pacific Exploring Expedition (1853-56). The collections made by Dr. Stimpson include, among other groups, thirty-three species of Nemerteans, obtained at points along the coasts of North America and Asia, though principally from Japan and China.

Stimpson arranged his thirty-three species under seventeen genera, of which the following ten were new: Diplopleura, Taniosoma, Dichilus, Cephalonema, Emplectonema, Diplomma, Dicelis, Polina, Tatsnoskia and Cosmocephaalia.' One half of the new genera have now proved synonyms. Thus Diclilus and Cosmocephialia = Amphiponis (Verrill '92); Taniosoma $=$ Estpolia (Bürger '95 (2)); Polina, according to Bürger = Eupolia, but according to Verrill =Ampliporus. Those of the other half (viz. Cephalonema, Diplomma, Dicelis and Tatsnoskia) have not, to the knowledge of the present writer, been identifed with any of the valid genera of the present day. Their fate must await further work upon these Japanese and Chinese forms. Of the remaining seven genera; four (Lincus, Corebratulus, Valencinia and Tetrastemina) were well recognized at the time Stimpson wrote, and are still valid; while three (Meckelia, Polystemma and Serpentaria) are synonyms of Cerebratulus, Ampliporus and Cercbratulus respectively.

Two of the ten new generic terms invented by Stimpson rep-

1 His classification throughout is soperficial and based in the main upon trivial external characters. 
resent valid genera, and, as Verrill ('95) has urged, should, by virtue of priority, supersede those now generally accepted by European writers. Emplectonema is sufficiently well defined, so that "Sicher ergiebt sich trotz der unvollkommenen Diagnosen dass 49 und 55 mit Eupolia und 52 (Emplectonema) mit Eunemertes zusammenfallen." (Bürger'952). As Emeplectonema long antedates Eunemertes (Vailant '90), it should stand for this genus. Similarly Diplopleura is at once recognized as identical with Langia (Hubrecht '79) and has priority.

Owing to loss of plates and material in the great Chicago fire, Stimpson was unable to publish his detailed descriptions and colored drawings. The Prodromus, accordingly, together with a brief paper on Chinese and Japanese forms (1855), represents, to the knowledge of the present writer, all the published work upon North Pacific Nemerteans up to date.

Of the species obtained by the present writer, one (Emplecto nema viride Stimpson) was described in the Prodromus; the other (Emplectonema violaccum Bürger) was described by Bürger ('96) from the Chilian Coast, while the remainder do not seem to have been noticed by either. Among the latter is one form of special interest in that its genus, which represents a transitional type, has heretofore been represented by two species only, both of which are very rare. This form which occurs abundantly in the Puget Sound region, is a new species of Carinoma. In order, however, to make clear the relationships and significance of Carinoma, it will be necessary to briefly trace the historical development of Nemertean taxonomy.

One of the most servicable taxonomic systems was that proposed by Max Schultze in 1852 , which divided the Nemerteans into the well-known ENOPLA and ANOPLA, based upon the rerespective presence or absence of calcareous stylets in the proboscis. Although this system was generally accepted and adopted in the older text-books, it finally became evident that the mere presence or absence of stylets is no certain indication of affinity. Thus forms are known whose inner organization in other respects conforms to the Enoplous type, yet lack the stylets (e.g., Malacobdella, Pelagonemertes). Moreover, the Anopla

AnNaLs N. Y. ACAD. SCI., XI, July 30, 1898-14 
proved a very heterogeneous assemblage, since under this term forms were included that differ as widely from each other as they do from the Enopla (e.g., Carinella, Cephalothrix, Cerebratulus). These faults were partially removed by Hubrecht ('79) in the following system :

\section{Palfonemertini.}

No deep lateral fissure on the side of the head. No stylet in the proboscis. Mouth behind ganglia.
Carinella, Polia, Cephalothrix, Valencinia.

\section{SCHIZONEMERTINI.}

A deep longitudinal lateral fissure on each side of the head, from the bottom of which a ciliated duct leads into the posterior lobe of the ganglion. Lateral nerves between the longitudinal and inner circular muscular coat of the body wall. Nervous tissue deeply tinged with hamoglobin. Mouth behind the ganglia.
Linesus,
Borlasia,
Corcbratulus, Langia.

3. Hoplonemertint. -

One or more stylets in the proboscis. Mouth generally situated before the ganglia. Lateral nerves inside the muscular coats of the body-wall. No deep longitudinal fissures on each side of the head.

\section{Drepanophories, Tctrastemma, Otrstedia,}
Ampliporus, Prosorhochmus, Nernertes.

The above system, the result of a deeper study of the inner. organization of these worms, marked an important advance in taxonomy. A single character (presence or absence of stylets) is here no longer taken as the basis of division, but a group of characters; and, moreover, the importance of the number and 
position of the muscular coats of the body-wall in relation to the nerve cords commences for the first time to be recognized.

But excellent and serviceable as the Hubrechtian system was, it still possessed a defect which became more conspicuous with increase of our knowledge of the comparative anatomy and embryology. It still associated under the term PALEONEMRRTINI such forms as Carinella, Cephalothrix and Polia ( = Eupolia Hubrecht ' 87 ), the last named type being more closely related to the Schizonemertini than to Carinella. The following sentence from Oudemans (' 85 ) shows how quickly this defect became obvious.with careful comparative study. " Though the families of the Valencinuida and the Polidide belong to the PALEONEMERTRA, they, with respect to their vascular and nephridial system, already approach the Schizonemertea. To avoid confusion, I will here employ the expression, "Palzo-type," "Schizo-type" and "Hoplo-type." Bürger ('go) went even further, and, after a severe criticism of Hubrecht's system, proposed a return to the Anopla and Enopla of Max Schultze. During the next two years, however, Bürger (' 91 and 'g2) elaborated and published a new system, which of all those heretofore proposed seems to come the nearest to expressing the true interrelationship of the main groups of Nemerteans.

Before taking up Bürger's system in detail we -must glance briefiy at the phylogenetic theories as influenced by the discovery of Carinoma. All are agreed that the epithelial position of the nerves in Carinella is a primitive feature. Accordingly the derivation of the remaining Nemertean orders from Carinella-like ancestors involves an inward migration of the nerve-cords. Even before the discovery of Carinoma a fairly complete series could be arranged from Carinella with its epithelial nervous system, through Cephalothrix with nerve-cords in the longitudinal layer, to Cerebratulus in which the nerve-cords have apparently migrated further inward to lie closely appressed (and sometimes indenting) the inner circular' muscle layer, leading finally to the Enoplous types with the ferves internal to all the muscular coats. (Compare figures in Hubrecht ' 87 .)

In 1875 McIntosh obtained at Southport, England, a spe- 
cies which he described as Valencinia armandi $\mathrm{n}$. sp. The careful description of this form by its discoverer (MacIntosh '75) and the able anatomical investigations of Oudemans ('85) made it clear that Valencinia armandi is not only the representative of a distinct type (allied to Cephlalothrix), but a form in many respects intermediate between Carinella and other Nemerteans. The special interest centers in the fact that anteriorly the nervecords lie in a similar position to those of Carinella (although surrounded by a thin layer of longitudinal muscles), while more posteriorly they break through the outer circular layer and lie for the rest of their course within the longitudinal layer. 'Oudemans was thus thoroughly justified in creating the new genus Carinoma for its reception. For twenty years the form remained the sole representative of its genus. In 1895 Bürger described the $C$. patagorica from some very scanty material collected at Punta Arenas, Patagonia. Of this material he observes: "O'ber ihr Aussehen im Leben fehlen leider Angaben." In C. patagonica the nerves lie wholly within the longitudinal muscle layer, so that within the limits of the genus Carinoma we have accomplished the theoretically required migration of the nerves through the circular muscle layer. It now became easy' to derive the Enopla directly from Carinella through Carinoma and Cephalothrix," while the Schizonemertean type (including the Eupolidx) comes off as an independent side branch from an ancestor of Carinoma, which retained the nerve-cords outside of the : circular muscles, but lost the inner circular layer and developed a new longitudinal layer beneath the basal membrane of which Carinoma armanda shows rudiments. ${ }^{\text {' }}$

These points are all clearly recognized in Bürger's taxonomic system. Carinella with Carinoma and Hubrechtia constitute the first and most primitive order ProtonemertinI; Carinoma and Cephalotlirix are ranked as an independent order MEsonemertini;

1 Cf. Burger '95 (2).

- Carinoma, while more primitive as regards the nerve-cords and presence of neptridia, seems to have lost the cephalic organs still retained in Cophalothrix (compare Joubin' 90 ).

- Such an ancestor Barger believes to be realized in Hubrechtia desidcratn ( $v$. Kennel). 
the Enopla constitute the MetanemertinI, while the remaining representatives of Hubrecht's Paleonemertini (viz., the Eupolidx) are grouped with the Sclisomemertini under the ordinal term HETERONEMERTINI.

Thus with the establishment of Bürger's system there appears to vanish the last vestige of artificiality in the ordinal classification, and for the first time we have a system that may be called a natural one.

\section{SPECIAL DESCRIPTIONS.}

\section{Protonemertist.}

\section{Carinella sexlineata n. sp.}

In form, color and internal anatomy this species very closely resembles $C$. superba (Kölliker), being marked by creamy white lines and annulations disposed upon a ground color of reddish brown. The principal difference lies in the pattern of the markings, which renders the form the most complicated of the genus.

Near the anterior margin of the head and well in front of the mouth occurs transverse band I (Fig. 15; I), which in the type specimen consisted of a broader dorsal and narrower ventral half meeting laterally in a sharp posteriorly directed angle. From band 1 there extends a mid-dorsal line the whole length of the body. A short distance behind the neck ${ }^{1}$ occurs band 2, which is broad and distinct, but interrupted laterally. whence proceed caudad two-paircd lateral lints.

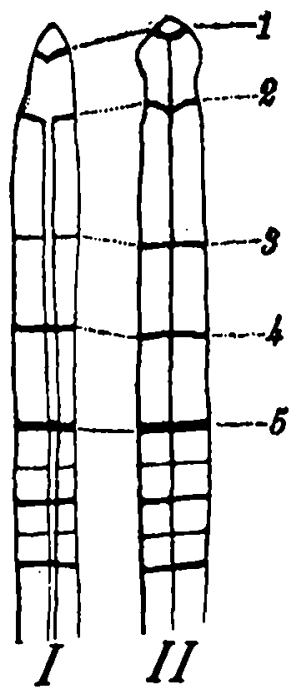
These. extend the whole length of the Fto. 55 . Coninella sextinteata body. A mid-ventral line also com-. mences from band 2 , arising from a flecked area involving the lower laterals.

n. sp. I. Lateral. II. Dorsel espect. Drawn from alcoholic specimens.

$1 N_{e c k}=$ constriction separating hesd from rest of body. 
The mouth is situated between bands I and 2 and in type specimen did not pierce band 2 (difference from $C$. superba). At intervals much greater than between $I$ and 2 occur bands 3,4 and 5 , with "no intermediate annulations. Band 3 is the broadest, its edges fimbriated, and interrupted between the laterals; 4 and 5 are more sharply outlined, 4 continuous, 5 partially interrupted at the laterals by the side organs (difference from both $C$. superba and $C$. annulatn, in neither of which do the side organs occur on a transverse band). The broken mid-ventral line continues nearly to band 5, where it breaks up into a row of fine dots which may be sometimes traced along the rest of the body. From band 5 to posterior extremity of body occur broad uninterrupted annulations sometimes double, placed some distance apart, with one to three finer intervening annulations, which are interrupted or nearly so at the laterals. The intervals between these body annulations are nearly equal.

VARIATIONS. It must be noted on behalf of the validity of this species that the above outlined pattern is in its main features remarkably constant. The variations, so far as was observed, involve merely the shade of the ground color, the amount of flecking, the composition (i. e., whether full or broken) and extension of the lines. The few specimens obtained near Sitka, Alaska, were darker in color, with much less flecking and fimbriation of the annulations. Those taken about Puget Sound showed congiderable flecking on the head behind band $I$ and on dorsum, mostly near lines or bands. Moreover, in some specimens the lines are more continuous, in others more or less dotted or broken.

In alcohol the worm darkens considerably, but even then the main pattem can be easily made out. The side-organs then appear as white circular spots.

Internal Anatomy. A cephalic'gland is absent as in $C$. superba. Differs from latter in general absence in region of side organ of a pronounced dorsal and ventral decussation of the circular muscles of the body-wall. A fine raphe of connective tissue is generally present in its place, which may involve a few muscle-fibers. In one individual sectioned these were 50 abun- 
dant as to produce a decussation similar to $C$. supcrba. The variation of this structure would appear to show that but little reliance can be placed upon it for specific determinations. A layer of longitudinal muscle fibres separates the cesophagus from the circular muscles of the rhynchocoelom as in C. nibicunda. Cephalic organs consist of a paired ciliated tube which penetrates the epithelium to end blindly next the basal membrane. Nephridia consist of branching tubules, portions of which bulge more or less into the lateral vessels. They open at their pos- . terior extremity by a pore above the side organs, $i$. . e, in transverse band 5 .

Habitat and Distriaution. Dredged in Kilisut Harbor opposite Port Townsend, in from 3 to 4 fathoms, also taken under bark of wharf-piles in its tough hyaline tube, as well as in the sand between tides. Likewise taken in and about Sitka Harbor, Alaska.

This worm grows to a great length; some incomplete fragments when fully extended were over a meter in length.

\section{Carinella rubra n. sp.}

\section{P. C. miniata Hubrecht. ${ }^{\prime}$}

Color in life a uniform bright red. In alcohol the pigment quickly washes out, leaving the worm a dull gray. The mature worm reaches an enormous length, some of the smaller individuals (incomplete) measuring over $140 \mathrm{cms}$., while the largest observed must have been at least two meters in length.

InTERnal Anatouy. Well developed glands fill the head (differences from $C$. polymorphia). Cephalic organs are epithelial pits which do'not reach the basal membrane. Dorsal and ventral decussation of circular muscles absent or very weak.

Habitat and Distribution. Taken in sand and silt between tides at Puget Sound (Bremerton), Kilisut Harbor, and Sitka, Alaska.

1 Burger ('95) figures a red species (C. mininta Hubrecht) which may possibly be identical with this species, bus since no sections were obenined its identity with $C$. rabra can be but a matter of conjecture. In. color, size and form of head they differ not a little. In form and size $C$. rubra more nearly reserables $C$. polyworpha. 


\section{Mesonemertini.}

\section{Carinoma mutabilis n. sp.}

Color a pure creamy or milky white, with faint cloudy mottlings in intestinal region, which cease a short distance from the posterior extremity, leaving the tail region pure white.

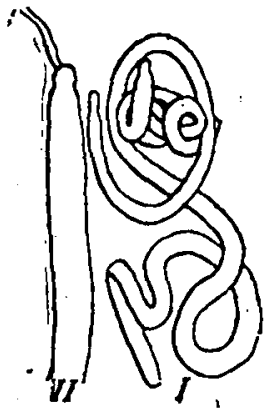

Fig. I6. Carinoma muta-

bilis $n$. I. Two in dividuals of type. II. but three or four cross sections of them variety argillina. Camers lucida from alco. bolic material. individuals of the type measured $14 \mathrm{cms}$. by $1 \mathrm{~mm}$. in alcohol.

Head hemispherical, narrower than body and marked of from latter by a slight narrowing or neck. No eyes or caudal cirrus.

INTERnal ANatomy. This species approaches very closely the $C$. patagonica Bürger('95). It appears to differ, however, in several particulars, especially in size and in the disposition of the nephridial tubules. The latter are large and loosely ramified, appear in each section and, although some of the branches are situated close to the

Length and breadth variable, the largest blood vessels, they do not appear to bulge into them to the extent that they do in $C$. patagonica. They open to the exterior by a single-paired excretory pore, the position of which varies in different varieties, though always dorsal to the nerve-cords." Circulatory system in its main features as in C. patagonica. Ventro-lateral blood vessels thick-walled, thickness of which steadily increases as nephridial region is reached. This peculiarity can be traced throughout the nephridial region. ${ }^{1}$ Dorso-lateral vessels thin-walled throughout. Dorsal and ventral nerves anteriorly outside the outer circular muscle-layer. A double diagonal muscle-layer commences to appear in the anterior osophageal region.

Inner circular-muscle-layer much thicker anteriorly than in C. patagonica.

${ }^{1}$ Compare similar phenomenon figured by Mclntosh ('75). 
Just in front of the nephridial region the following changes occur :

$I^{\circ}$. Inner circular-muscle-layer becomes enormously thickened.

$2^{\circ}$. Dorsal and ventral nerves commence to break through the outer circular-muscle-layer and dip down toward the inner layer.

$3^{\circ}$. Lateral nerve cords commence to break away from the inner side of the outer circular-muscle-layer and sink deeper into the longitudinal layer.

$4^{\circ}$. Diagonal muscles commence to thin out, to disappear completely a short distance further back.

Proboscis-pore subterminal, cephalic lacunæ extend to tip of head. A cephalic gland is present in type specimen. It consists of deeply staining lobules that hang into the cephalic lacunæ anterior to the proboscis pore. ${ }^{1}$ Brain, with lacunæ and rhynchocoelom in brain region, more or less completely inclosed in an inner capsule of connective tissue separated from basal membrane by a thin longitudinal muscle-Jayer. Mesenchyme scanty.

Habitat and Distribution. In sand between tides and on piles of wharves, along the west shore of Port Townsend harbor, between the wharves of the city and the railroad depot.

Two varieties of this species were taken, which for convenience of reference will be distinguished by varietal names.

\section{Carinoma mutabilis argillina $n$. var.}

General form and color as in type. The entire worm was not obtained; the largest fragment measures $15 \mathrm{cms}$. by $3 \mathrm{~mm}$. in alcohol. Differs from type in larger size, rather more powerful muscular development. Excretory pore in csophageal region where inner circular-muscle-layer is still thick, and anterior to cessation of dorso-lateral vessels, i.e., slightly further cephalad than in type. Mesenchyme rather more extensive, lateral halves meeting in mid-ventral line behind mouth.

1 Burger ('95(1)) makes no reference to a cepbalic gland in $C$. pragonica, and $\langle$ ' $95(2)$ ) is not quite sure of its presence in $C$. armandi. 
Habitat and Distribution. Between tides in hard blue clay among pholads, not apparently in burrows of latter, but in surrounding clay, to all appearances excavating burrows of its own.' Locality, west of Point Wilson on shore of Strait of Juan de Fuca.

\section{Carinome mutabilis rasculosa n. var.}

Form and color as in type, size intermediate between type and var. argillina. Mesenchyme most extensive, in cesophageal region nearly surrounding the very large blood vessels. Ventrolateral vessels branch from time to time. Excretory pore at commencement of visceral region where inner circular-muscles thin out.

Habitat and Distribution as in type, except that it was not taken on piles.

All these varieties build sand-tubes and in mode of life resemble somewhat Cerebratulus, though they do not swim nor readily fragment themselves as do the cercbratulids, and appear generally more sluggish.

\section{analytical Key to Spectes of Carinoma.}

A.-Nerve cords anteriorly without circular muscle layer; further back they break through the latter, and lie wholly within longitudinal layer. .C. armandi (McIntosh) Oudemans.

B.-Nerve cords wholly within longitudinal layer throughout their entire course.

a-Small (3.5. cms.). Brain free in longitudinal muscles of head. Nephridia bulge far into thin-walled blood vessels. Dorsal and ventral nerves wholly within outer circular-muscles-layer throughout their entire course. C. patagonica Bürger.

P-Large ( $14-15 \mathrm{cms}$.). Brain enclosed in connective tissue capsule. Nephridia do not bulge so far into the thick-walled bloot vessels. Dorsal and ventral nerves anteriorly without outer circularmuscle-layer; further back break through same...C. mutabilia Mihi.

IIf this be truc, the sact is interesting because of the soft-bodied nature of the animal. The annelid Halh ? is known to bore in the till (Herrington and Grifin, '(6), bas this animal, unlike the Nemertean, bas powerful jaws and a from exo. skeleton. Herreofore no Nemertean has been known to bore in so hard a subsuance (McIntosb, '68). 
Metanenaertini.

6. Emplectonema Stimpson, 1857.

1873 Nemertes McIntosh (nec Cuvier 1817 ).

1873 Macronomertes Verrill.

1890 Eunemertes Vaillant.

This genus is defined by Stimpson as, follows: "Corpus longissimum subfiliforme, depressum, proteum. Caput subdiscretum, stricturis nullis, fovea longitudinali in utroque margine antero-laterali. Ocelli plurimi." Later writers (including McIntosh, Vaillant, and Bürger) have added the following anatomical characters to the definition. Mouth opens into the rhynchodeum; proboscis very short; rhynchocolom restricted to anterior third of body; cerebral organs very small and far in front of brain; head gland but rarely reaches to brain.

\section{Emplectonema viride Stimpson, 1857.}

Stimpson gives the following description of this species in his Prodromus: "Corpus depressum, lineare v. proteum, supra viride, subtis album. Caput subdiscretum, marginibus àlbis ; foveis elongatis'bipartitis ; fronte emarginata. Ocellorum acervi quattuor; posteriores distincti, rotundati, ocellis confertis ; anteriores marginales juxta foveas, occellis sparsis. Long. II lat. 0.05 poll. Hab. in portu 'San Francisco' littoralis inter lapillos."

The form here referred to $E$. viride occurs widely distributed from Puget Sound to Alaska, and shows no local variations, the same varieties being found in all localities visited. As a general rule, however, the specimens from the more northern latitudes are darker in hue.

Length of largest specimen nearly I m., breadth I-2 mm., head spatulate, emarginate in front, not especially marked off from body, not wider than body.

Three cofor-varieties-are common: (I) A slender and smaller form, very light olive green, (2) a much darker green form which shows on head and anterior portion of body, a mid- 
dorsal longitudinal line, and one transverse band at neck (fig. 17 , (3), a form almost black and not showing the lines that characterize No. 2. All three varieties agree in the much lighter ventral portion marked off from darker dor-

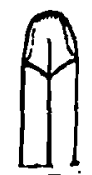

F1G. 17. Emiplectonema viride Stimpson. Showing pattern on head. sum by sharp line of demarkation. Anterior and lateral margins of head in all three varieties very light almost white. Eyes numerous, distributed along side of head, on each side of demarkation-line between light margin and dark dorsum. The colors keep fairly well in alcohol, darkest green, paler, palest olive, and even bluish varieties can be distinguished. Some specimens from West Berkeley, California, became gray in alcohol.

InTERnal ANatomy very similar to E. gracile. Mouth opens into rhynchodeum; cephalic organs some distance in front of brain; canals from cephalic organs run forward to openventrälly in region of proboscis-pore; proboscis-pore ${ }^{1}$ some distance from tip of head.

Intestinal cæca do not quite extend to brain. Central stylet of proboscis with very long basal portion, two marginal stylet-pockets are present, each containing five long curved sty- FIG. 18. Emplectonema viride. lets. Ducts from these marginal pockets appear to be dilatable proximally (fig. I 8 ). In some specimens preserved in alcohol the stylet gland and basal portion of central stylet are a bluish green in color and contrast strongly with the adjoining non-pigmented portion of the proboscis.

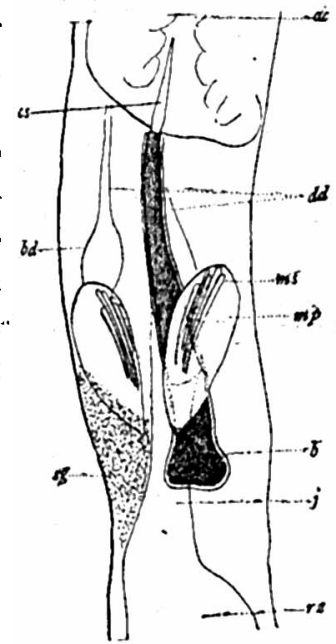

Stylet and region of proboscis. ar.- anterior chamber. cs.Central stylet. dd.--ducts of marginal pockets. bd.-basal dilation of same. nis.-mar. ginal stylets. mip.-marginal pockets. 6. - besal portion of central stylet. f.-ejaculatory duct. ss. -stylet gland. rz.--ieservoir.

In instances like this where the mouth opens into the rhynchodeum the common opening ("gemeinschaflicbe Oeffnung" Bunger) will be called proboscis-pore. 
This species very strikingly resembles $E$, gracile Johnston. It may be distinguished by its narrower head with sharply defined color patterns and general darker hue of body.

Habitat and Distribution. Taken on piles, on and under stones at Port Townsend, Washington ; Fort Wrangle and Sitka, Alaska. The type locality. (Stimpson) is the bay of San Francisco. Its range; as so far determined, is then from San Francisco to Sitka.

\section{Emplectonema violaceum Bürger, i 896 .}

\section{Etmemertes violaca Bürger.}

In life this form secretes an enormous amount of slime in which it lies coiled up in tangled knots. It was found next to impossible to straighten it out sufficiently for accurate measurement, but its length was estimated to be at least $50 \mathrm{cms}$. Broken fragments in alcohol measure over $30 \mathrm{cms}$. Shape extremely flattened, ribbon-like. Head rounded in front, directly continuous with body. Color varies somewhat, though a fairly constant pattern is presented on dorsum, which is densely flecked with purple or brown upon a pale yellowish brown ground color. Ventral portion yellowish white. Eyes numerous.

The Internal Anatomy agrees more or less closely with Bürger's (' 96 ) description. It "does not possess a powerfully developed head gland. The cerebral organs are very small and lie very far in front of the brain. Many small eyes are present. The osophagus opens into the rhynchodeum." Powerfully developed integumentary glands are present throughout the body.

Habitat and Distribution. On piles about Port Townsend, coiled in a tangled mass, and enveloped in its mucus. The type specimens of Bürger were obtained near Calbuco, on the coast of Chile. Its range is thus quite extensive.

The great amount and tenacity of the slime proves an obstacle to its proper preservation, as a coagulation of the slime apparently hinders the thorough. penetration of the alcohol. 


\section{Amphiporus imparispinosus n. sp.}

Length in alcohol, $40-45 \mathrm{~mm}$. Breadth, 1-2 mm. Color, white. Head in extension hemispherical, broader than body.

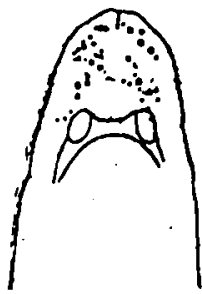

Fic. 19. Amphiporus imparispinosws a. sp.

Curnera lucide, from living worm un. der influence of chloral hydrate and compressed under cover slip.

Eyes numerous ( $23 \pm$ on each side), distributed in two elongated concentric groups along antero lateral to lateral margin of head, not extending behind brain as in Zygonemertes viresccus (Verrill) (fig. 19). Body widest anteriorly, tapering off to a slender posterior extremity.

InTERnal ANatomy. Mouth opens into rhynchodeum. Cephalic gland not prominent. Cephalic commissure ${ }^{1}$ above proboscis-pore. Cephalic organs in front of brain, dorso-lateral . to ventral ganglia, opposite mouth; the canals open ventrally just behind proboscis-pore. Nephridia commence behind brain and open to exterior by numerous efferent ducts, just dorsal to nerve-cords. Nephridia cease just behind $2 \mathrm{~d}$ or $3 \mathrm{~d}$ pair of gonads. Intestinal cxica extend to brain. Apparently no integumentary glands in body. Rhynchocœlom does not extend quite to posterior extremity. Central stylet as long as basal portion, latter constricted in middle (fig. 20). Three marginalstylet-pockets, each containing two stylets.

This species is apparently to be distinguished from $A$. dubius Hubrecht, by its numerous eyes and paler color, and from A. Greenmanni Montgomery, by its larger size, greater number of eyes and distribution of eyes and color of body.

Habitat and Distribution. On piles and stones, Port Townsend and Sitka.

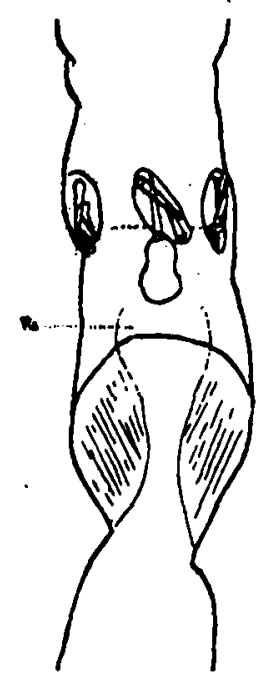

FIG. 20. Amphiporus imsparipinosus n. sp. Stylet region of proboscis. Camena lucida from to tal preparation. Rs. reservoir.

${ }^{1}$ By cephalic commissure is bere meant that connecting the blood ressels anteriorly. 
ro. Amphiporus formidabilis n. sp.

Length in alcohol $9+\mathrm{cms}$. Breadth $2 \mathrm{~mm}$. Form and color as in preceding species except for flesh-colored tinge anteriorly. Visceral region dull gray. Eyes very numerous

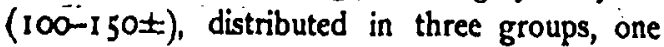
antero-lateral paired group and one median unpaired group. The latter is V-shaped and situated just in front of brain, with the limbs directed backwards and merging into two gray streaks that extend along each side for a varying distance caudad (fig. 22).

INTERNaL ANatomy. Mouth opens into rhynchodeum. Head densely packed with cells of cephalic gland. Cephalic commissure just pos-

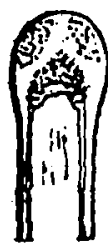

Fic. 21. Aimplipipa ros formidabilis. Free-band from living worm. terior to proboscis-pore. Cephalic organs in front of brain, opposite mouth, canals open laterally behind proboscis-pore. Intestinal caca extend to brain. Nephridia open by numerous efferent ducts, some of which open dorsally, others laterally. Integumentary glands abundant in anterior portion of body. Rhynchocol extends to end of body.

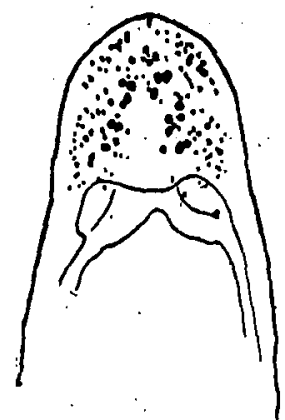

FIC. 22. Amphiporis formidadilis. Camere lucide from worm under influence of chloral hy. drate under covers-slip.

Central stylet shorter than its basal portion. Marginal stylet-pockets arranged in a continuous row around the central stylet. Their number appears to be either $8 \pm$ or $12 \pm$. Each contains two stylets.

In number and arrangement of the marginal stylet-pockets this form bears close resemblance to $A$. spinosissimus Bürger and $A$. pugnax Hubrecht, but differs in numerous anatomical points from $A$. spinosissimus, especially in the position of the excretory pores.

Habitat and Distribution. On piles of wharves, and on stones and rocks along with A. imparispinosus and Emplectoncma siride. Puget Sound and Alaska. 


\section{Amphiporus brunneus n. sp.}

Length in alcohol of largest individual $3.3 \mathrm{cms}$. Breadth 5 mms. Color (in life) dark brown or smoky black on dorsum, greenish or yellowish white ventrally. On each side of neck is a pale angular spot.

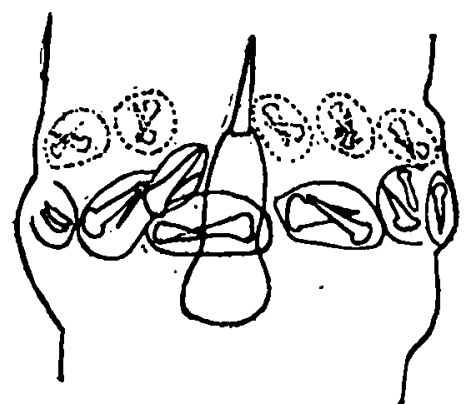

Fic. 23. Amphiporns formidabilis n. sp. Stylet region of proboscis. The dotted pockets and stylets filled in diagrammatically, the rest from camera lucida drawing

Internal Anatomy. Proboscis - pore subterminal. Cephalic gland moderately developed. Cephalic organ considerably in front of brain. Cephalic canals open opposite mouth. Intestinal cæca extend almost to brain. Anterior portion of proboscis very long; in ordinary protrusion the stylet-region remains within the everted anterior chamber. Basal portion of central stylet long, two marginal pockets each containing two (or three ?) stylets. ${ }^{1}$

Habitat and Distribution. On piles and rocks about Port Townsènd.

\section{Amphiporus angulatus (Fabr.) Verrill?}

I have provisionally referred to this species a form that occurs (though not very abundantly) under stones near lowest low water mark in Sitka Harbor, Alaska. But two alcoholic specimens are now available for description. ${ }^{2}$ It readily contracts into a thick oblong mass.

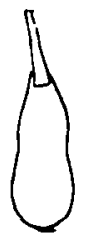

Fic. 24. Amphiponus brunnews. Central stylet. Camera lucida.

' Rhynchoccel sunounded by a thin circular muscle sheatb, within which is a layer of longitudinal muscles.

Owing to these two specimens having been collected too late to be packed with the rest of the Alaska material, they were placed in the witer's microscope case, and were therefore saved when the ship went down. 
Length in alcohol, 4-7 cms. Breadth, 5-6 mms. Color (in life) a reddish purple on dorsum, white ventrally. Head with prominent marginal white spots at neck.

Internal Anatomy. Cephalic gland fairly well developed; proboscis-pore sub-terminal and anterior to cephalic commissure. Cephalic canals enter ventrally and run caudad for some distance in the epithelium. In the region of the mouth they break through the circular muscles to reach the cephalic organs. ${ }^{1}$

Cephalic organs large, considerably in front of brain. Mouth opens into rhynchodeum. . Dorsal commissure fairly large. Intestinal crca short, do not extend near to brain. Anteriorly the integumentary glands are very abundant ventrally, sparsely distributed dorsally. Rhynchocoel surrounded by thin sheath of outer circular and inner longitudinal muscles. In visceral region gonidial pockets are numerous; a single section shows several, distributed dorsally and laterally to the intestine.

Habitat and Distribution. Under stones near lowest low water mark. Sitka Harbor and Redout Bay, Alaska.

Besides $A$. brunneus there are several other forms that bear a more or less general resemblance to $A$. angulatus, and are to be classed among the boreal species. Stimpson's Cosmoccphala Beringianus and $C$. Japonicus are both believed by Verrill ('92) to be varieties of $A$. angulatus. At Sitka the present writer obtained three quite similar forms (sizes quite different) which seem to approach $A$. angulatus. When studied under a lens they were seen to possess two paired white lines between which, in two of the forms, the cervical white patches were situated, so characteristic of $A$. angulatus. In the third these angular patches seem to have been absent or represented by a faint paling of the ground color. Each of the three, with $A$. angulatus seemed to characterize a particular zone of the beach between hlgh and low water mark.

1 The one specimen sectioned showed an interesting abnormality in the cephalic canal and organ of one side (left?). On this side the cephalic organ lay much further caudad so as to be opposite to the ventral commissure, while its canal forked in the epithelium, one branch opening dorsally, the other more ventrally. The cephalic organ of the right side lay considerably in front of brain.

Annals N. Y. ACAD. SCI., XI, August 13, 18g8-15. 


\section{Amphiporus drepanophoroides n. sp.}

Color red above, white below. Length probably not over 4-5 cms. Form short and stout. Eyes numerous in rows along antero-lateral margin of head.

Internal Anatomy. Proboscis-pore terminal. Cephalic gland prominent. Integumentary glands also prominent in head, all situated ventrally and ventro-laterally. Further back they commence to thin out (at first in the mid-ventral line) and disappear completely a short distance behind brain. Mouth opens into rhynchodeum. Cephalic organs large, anterior portion opposite ventral commissure, closely pressed against brain, further back they become pushed in between dorsal and ventral ganglia and extend back of dorșal ganglia. Their canals open laterally in front of ventral commissure. Differs from all the preceding Amphiporids in the smallness of the rhynchocol, and in having the latter enclosed in a thick muscular sheath in which longitudinal and circular muscles are interwoven. No forwardly extending intestinal cæca. Circular muscle-layer quite thick.

\section{HETERONEMERTINI.}

14. Lineus striatus $\mathrm{n}$. $\mathrm{sp}$.

Owing to loss of all color notes and drawings by shipwreck, no dctailcd description can be here given of its appearance during life.

Color brownish red on dorsum, sharply marked off laterally from the much lighter ventral portion. Dorsum marked by numerous creamy white transverse bands which cease at the demarkation-line between the dorsal and ventral coloring. Tip of head brilliant red. Length probably not over $4 \mathrm{cms}$.

This form seems from the above quite similar to Micrura fasciolata, yet it is at most but one-half the size of the latter, much flatter, the pattern much sharper and constant, and in all specimens obtained no cirrus was present. For these reasons it must at present be referred to Lincus. 
Internal Алатомy. Nephridial system with numerous efferent ducts opening dorsally to the nerve cords. In one section two ducts occurred, one slightly dorsal to the other.

Habitat and Distribution. Under stones and in sand between tides, Kilisut Harbor, and Bremerton. Not taken in Alaska.

\section{Lineus sp. -}

This species, which appears to be new, was found among a mass of hydroids that had been preserved in formalin. The single specimen measured $5.2 \mathrm{cms}$. by $5 \mathrm{mms}$; it was an entire worm. Color smoky black with greenish tinge on dorsum, gray-brown ventrally.

IntERnal ANatomy. Cutis richly supplied with gland cells of which two kinds occur, one staining with hæmatoxylin, the' other with congo-red. In this respect the cutis is similar to the epithelium.

Habitat and Distribution. Among hydroids (Diphasia) about Port Townsend.

\section{I6. Cerebratulus marginatus Renier.}

I have referred to this species a smoky black form that occurs abundantly in the sand between tides at Port Townsend and Bremerton. Most of the specimens differed from the Neapolitan form figured in Bürger's monograph, in lacking the white coloration on the posterior extremity, and the white rims to the cephalic furrows. As the specimens showed variation in this regard, some approaching quite closely the typical form, and as the internal anatomy is indistinguishable from that of specimens from Naples, I have referred this form to $C$. marginatus.

\section{I7. Cerebratulus sp.}

Portions of a very large dark form with flesh-colored lateral margins were obtained. Some of the fragments in alcohol measure nearly $20 \mathrm{mms}$. in diameter. In internal anatomy it seems to approach $C$. marginatus; the rnly noticeable point of difference appears to be that the cephali: slits cease at least 
Io sections (each cut at least $30 \mu$ thick) in front of mouth. In C. marginatus they cease in the section in which the mouth commences.

\section{SUMMARÝ.}

Of the fourteen species treated in the foregoing; nine appear to be new and peculiar to the. Pacific coast of North America ; two (Emplectonema viride and E. violaceum) are already described, although likewise peculiar to the west American coast ; one (Amphiporus angulatus) with three problematical forms are boreal and are represented on the north Atlantic coast, and one (Ccrebratulus marginatus) is cosmopolitan. Among the forms peculiar to the west coast are a few that show remarkably close resemblance to west European forms. Thus Carinella scxlincata is the Pacific representative of $C$. superba, while $C$. rubra resembles C. miniata. Emplectonima viride is very closely similar to E. gracile. Lineus striata resembles Micnura fasciolata. ${ }^{1}$ Another conspicuous fact is the complete absence of Atlantic American species, outside of the strictly boreal forms such as Ampliporius angulatus. No banded Carinellas occur on the east coast ${ }^{2}$, no Carinoma has as yet been found. The east coast Amphiporids and Lineids are either unrepresented on the Pacific or replaced by different species. The noticeable scarcity of Lineus on the west coast is perhaps to be correlated with the superabundance of different forms of Ampliponis, which apparently replace them functionally.

Zoblogical Laboratory OF COLUMBIa UNiversity, March, 1898.

IIf it can ever be shown that $L$. striate actually does possess the cirrus, and bence in a micruran, this parallel will be further strengthened.

2 Except the "large Canadian Carinella dredged in the Gulf of St. Lawrence by Mr. Whiteaves." Mlintosh '75. 


\section{LITERATURE.}

Bürger, O., 1890. Untersuchungen itber die Anatomie u. His. tologie der Nemertinen, nebst Beiträge zur Systematik. : Zeitschr. wiss. Zoöl. 50.

Bürger, $0 ., 189 \mathrm{r}$. Vorläufige Mittheilungen über untersuchungen an Nemertinen des Golfes v. Neapel: Nachr. d. k. G. d. Wiss. v.d. Georg-Augusts-Univ. zu Göttingen.

Bürger, O., 1892. Zur Systematik der Nemertinenfauna des Golfes v. Neapel. Vorl. Mitthl : Nachr. d. k. G. d. Wiss. zu Göttingen.

Bürger, O., 1895 (1). Beiträge zur Anatomie, Systematik und geographischen Verbreitung der Nemertinen: Zeitschr. f. Wiss. Zoöl. 6r.

Bürger, O., 1895 (2). Die Nemertinen des Golfes v. Neapel: Fauna u. Flora des Golfes v. Neapel. $22^{+1}$ Monographie.

Bürger, $0 ., 1896$. Meeres und Land-Nemertinen gesammelt v. den Herren Dr. Plate u. Micholitz. : Zoöl. Jahrb. Ab. d. Syst. $Q$.

Hubrecht, A. A. W., 1879. The Genera of European Nenerteans critically revised, with descriptions of several new species: Leyden Mus. Notes, Vol. I.

Hubrecht, A. A. W., 1887 . Voyage of H. M. S. Challenger, 1873 76. Nemertea. Zoöl. XIX.

MacIntosh, W. C., 1875 . On Valencinia Armandi, a new Nemertean: Trans. Linn. Soc., London, Ser. 2 Zoöl., Vol. I.

Oudemans, A. C., 1885. The Circulatory and Nephridial Apparatus of the Nemertean: Quart. Jour. Micr. Sci., XXV.

Stimpson, W., 1855. Description of some of the new Marine Invertebrata from the Chinese and Japanese Seas: Proc. Acad. Nat. Sci., Phila.

Stimpson, W., x857. Prodromus descriptionis Animalium Evertebratorum, qux in Expeditione ad Oceanum Pacificum Septentrionalem, a Republica Federata missa, Calwaladaro Ringeold and Johanne Rodgers Ducibus, observavit et descripsit. Pars. ii Turbellarieorum Nemertineorum: Proc. Acad. Nat. Sci, Phila.

Vaillant, L., 18go. Térétulariens: Hist. nat. des Annéles (Collection des Suites d Buffon), Tome 3, Paris. 
Verrill, A E., 1873. Results of Recent Dredging Expeditions on the Coast of New England: Am. J. of Sci. and Arts, Ser. 3, Vol. VI.

Verrill, A. E., I892. The Marine Nemerteans of New England: Trans. Conn. Acad., VIII.

Verrill, A. E., I895. Marine Nemerteans and Planarians of New England (Supplement); Trans. Conn. Acad., June. 